\title{
Cyberciało jako narzędzie komunikacji VR. Przegląd dostępnych rozwiązań
}

\author{
Jowita Guja (D), Adam Żąłło
}

AGH Akademia Górniczo-Hutnicza, Wydział Humanistyczny, Laboratorium EduVRLab, Kraków

Streszczenie: W artykule przyglądamy się zjawisku kulturowego dryftu w rozwoju technologii na przykładzie technologii Virtual Reality i odkrycia jej społecznościowego potencjału. Opierając się na obserwacjach prowadzonych od marca do końca 2020 roku, analizujemy typy rozwiązań przyjmowanych przez twórców społecznościowych aplikacji VR i próbujemy wykazać, że problemy tkwią nie tyle w niedociągnięciach technicznych, ile założeniach antropologicznych.

Słowa kluczowe: cyberciało, ciało, awatar, Virtual Reality, aplikacje społecznościowe VR, dolina niesamowitości, wizerunek

CYBERBODY AS A VR's COMMUNICATION TOOL. OVERVIEW OF AVAILABLE SOLUTIONS

Abstract: We look at the phenomenon of cultural drift in Virtual Reality technology development and the discovery of its social potential. Based on the observations conducted from March to the end of 2020, we analyze the types of avatar solutions adopted by the creators of social VR applications. We are going to show that their problems are located more in anthropological assumptions than in technical shortcomings.

Keywords: Cyberbody, body, avatar, Virtual Reality, VR social applications, uncanny valley, effigy https://doi.org/10.7494/978-83-66727-48-9_4 
Świat elektroniczny nie jest symulacja i nie ma w nim miejsca na symulacje ${ }^{1}$.

Sidey Myoo

\section{Wprowadzenie}

Artykuł prezentuje wnioski z badań prowadzonych od marca do końca 2020 roku w aplikacjach społecznościowych Virtual Reality (VR) - w momencie, w którym ze względu na wybuch pandemii i wprowadzony lockdown zyskały one niespotykaną wcześniej popularność, a także mocne wsparcie deweloperskie. W badaniach analizowaliśmy typy konstrukcji awatarów stosowanych w tych aplikacjach, co doprowadziło nas do tezy, że ich główne niedociągnięcia wynikają raczej z założeń antropologicznych niż z braków technologicznych.

\section{Kontekst badań}

Doświadczenie izolacji w trakcie epidemii COVID-19 sprawiło, że dla znacznej części społeczeństwa komunikacja wirtualna stała się elementem codzienności, zarówno w pracy jak i w życiu prywatnym. Przez wiele miesięcy w kontaktach społecznych pośredniczyły Skype, Zoom, GSuite, większego znaczenia nabrały także klasyczne aplikacje społecznościowe, takie jak Facebook, Instagram czy fora dyskusyjne. Jednocześnie znacząco zwiększyła się popularność headsetów do odbioru wirtualnej rzeczywistości. VR kojarzący się dotąd przede wszystkim z eskapizmem, zanurzeniem w alternatywnym świecie w stopniu znacznie wyższym niż możliwy przy zastosowaniu innych rozwiązań cyfrowych, pokazał swój potencjał komunikacyjny. Do VR przeniosła się część festiwali filmowych, koncertów, spotkań roboczych czy konferencji. Już w pierwszych tygodniach marca można było zauważyć znaczny wzrost popularności aplikacji społecznościowych, takich jak Altspace czy Bigscreen, zaprojektowanych głównie z myślą o osobach dzielących zainteresowania. Do 2020 można było w nich spotkać jedynie pojedynczych pasjonatów VR. Wiosną 2020 gromadziły się tu już spore grupy ludzi, żeby pogawędzić, piekąc jednocześnie wirtualne kiełbaski przy wirtualnych ogniskach czy posiedzieć przy wirtualnym stole. Technologia, której atrakcyjność dotąd wiązano $\mathrm{z}$ aspektem eskapistyczno-eksperymentalnym, odsłoniła nowy potencjał: VR potrafi nie tylko wyrwać nas z tego, co „Zwyczajne”, ale i „zwyczajność” przywrócić w momentach, gdy „Real” zaczyna działać inaczej niż zwykle.

1 M. Ostrowicki (Sidey Myoo), 2008, Tożsamość człowieka w środowisku elektronicznym, Kwartalnik Filmowy, R. 30, nr 62/63, s. 151. 
$\mathrm{Na}$ zapotrzebowanie odpowiedzieli producenci szeregiem darmowych aplikacji: szybko doszlifowano wersje beta (Spatial), zwiększono dostępność aplikacji wcześniej skierowanych do wąskiego kręgu (Engage), rozszerzono funkcjonalności istniejących aplikacji, pojawiły się także rozwiązania zupełnie nowe (Alcove, Immerced). Społecznościowe aplikacje VR dzielą się ze względu na przeznaczenie: część z nich z założenia ma zastąpić biura i konferencyjne oraz wykładowe sale (Spatial, Engage), część służyć wspólnemu rozwijaniu hobby lub darmowemu dokształcaniu się (Altspace, Bigscreen), część ma być po prostu miejscem na spotkania towarzyskie (Alcove) i spontaniczną rozrywkę (VRChat).

Celem naszych badań była analiza strategii konstrukcji cyfrowych awatarów (cyberciał) pod kątem rozwiązań technicznych oraz założonych przez twórców modeli komunikacji. W naszych badaniach uwzględniliśmy aplikacje o największej popularności i dostępności w tym czasie: Altspace, Bigscreen, Engage, VRChat oraz Spatial.

Przez kilka miesięcy odwiedzaliśmy je jako użytkownicy i obserwatorzy, analizując konstrukcję najczęściej wybieranych awatarów, testując interakcje, a także nasze własne odczucia. Nasze badania mają charakter wstępny i pozwalają raczej na zidentyfikowanie obszaru badawczego oraz sformułowanie pytań niż jednoznacznych wniosków.

\section{Typy aplikacji społecznościowych w VR oraz rozwiązań}

\subsection{AltspaceVR - sympatyczny everyman}

AltspaceVR to jedna z najstarszych aplikacji społecznościowych wykorzystujących technologię Virtual Reality. Powstała w 2015 roku, wzbudzając duże nadzieje. Dzięki temu, że daje możliwość współdzielenia doświadczenia - pisał „Time” w 2016 roku odpowiada ona na najbardziej fundamentalny problem VR, którym jest samotność i izolacja użytkownika (Pullen 2016). Od początku dużym plusem była jej dostępność: jest darmowa i działa nawet na najprostszych goglach, takich jak Samsung Gear czy Oculus Go. Według deklaracji producenta Altspace jest „najlepszym miejscem do uczestniczenia w pokazach na żywo, spotkaniach, świetnych zajęciach - i wiele więcej wraz z przyjaznymi ludźmi z całego świata” (AltspaceVR, b.d.). W aplikacji organizowane są wykłady, panele, spotkania pasjonatów, w prosty sposób można utworzyć i spersonalizować własne wydarzenie. W czasie pandemii ogromną popularnością cieszą się np. spotkania poświęcone wspólnej medytacji.

Klasyczne awatary w Altspace (rys. 1) są mocno standaryzowane, mamy tutaj do czynienia z pełną, nieruchomą sylwetką. Postacie są podporządkowane jednej stylistyce i siatce poligonów. Aplikacja jest dzięki temu stabilna i lekka, jednak kosztem braku indywidualizmu w kreowaniu własnego wyglądu. Nasza rola projektanta kończy się na wyborze płci, koloru skóry i ubrania. Postacie nie mają mimiki i występują w dwóch 
wariantach: „robota” oraz postaci ludzkiej (męskiej lub żeńskiej) o łagodnym wyrazie twarzy. Awatary w tej aplikacji służą przede wszystkim wskazaniu naszej lokalizacji w cyfrowej przestrzeni. Są uproszczonymi ikonkami, w których miejsce w zasadzie można byłoby wstawić chmurkę z naszym inicjałem. $\mathrm{Z}$ drugiej strony jednak z założenia mają być „przyjazne”: stąd twarze, które odbieramy jako trochę „naiwne” i „poczciwe”, a także neutralne stroje i fryzury. Altspace z założenia nie chce dopuścić do wykreowania przez użytkownika awatara prowokującego, zmysłowego czy złowrogiego.

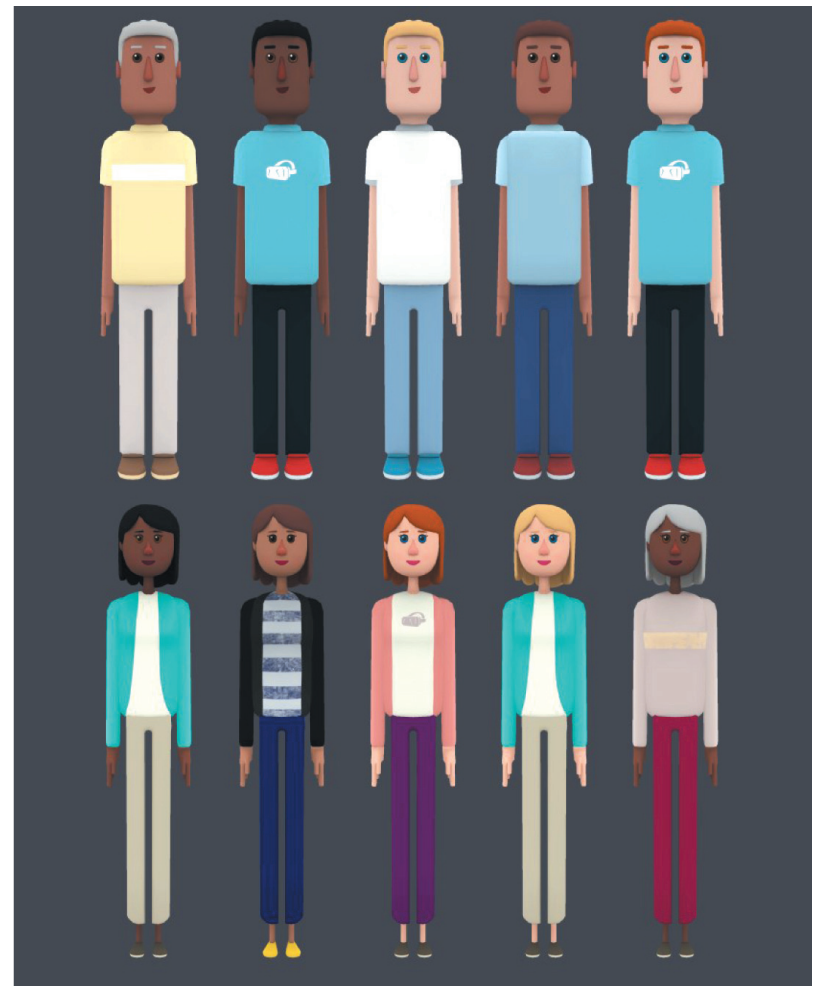

Rys. 1. Projekty awatarów w AltspaceVR

Źródło: https://altvr.com/new-avatars/ (lipiec 2020)

Mimo to w wyszukiwarce Google fraza „AltspaceVR sexual harrasment” generuje prawie 45 tys. wyników, więcej ma tylko „VRChat sexual harrasment” (77 tys.). VRChat jest jednak aplikacją o innym charakterze, służy nie tyle komunikacji, ile poszukiwania mocnych wrażeń. Daje także użytkownikowi pełną wolność w kreowaniu świata i awatara, pozwalając na ich samodzielne zaprojektowanie w Unity. Pokrewne Altspace są natomiast takie aplikacje, jak Bigscreen, Alcove, Immerced, oraz platformy o przeznaczeniu edukacyjnym, takie jak Engage. Przypadki molestowania i nagabywania w ich przestrzeni opisywane są sporadycznie. 
W dyskusjach na forach poświęconych VR użytkownicy, którzy doświadczyli takich zachowań, postrzegają je jako ogromny problem i najczęściej opisują jako wydarzenia traumatyczne - por. np. Controversy Regarding „VR Sexual Harassment” (b.d.), Sexual Harassment on AltspaceVR a problem? (b.d.). W trakcie naszych badań kilkakrotnie spotkaliśmy się z agresywnym nagabywaniem w Altspace. Osaczeni przez napierające na nas nieruchome, łagodnie uśmiechnięte twarze, które odbieraliśmy jak ożywione lalki lub kukły, doświadczyliśmy nieprzyjemnego poczucia niesamowitości i brutalnego naruszania granic naszej intymnej przestrzeni. Zastanawialiśmy się przy tym, czy do ataków nie prowokuje właśnie nasza „poczciwa”, bezbronna aparycja. Przyglądając się otaczającym nas postaciom, mieliśmy jednocześnie wrażenie, że twórcy aplikacji nieświadomie zastosowali chwyt znany z wielu dreszczowców: Chcesz straszyć? Użyj maski lub lalki z martwym spojrzeniem i o człekokształtnym, ale usztywnionym ciele, które nagle ożywa.

Pomijając to, komunikacja w postaci prostych, standaryzowanych awatarów Altspace okazała się sztuczna i mało komfortowa. Naszego rozmówcę odbieramy jak lalkę, z której nagle wydobywa się znajomy głos. Altspace nie sprawdziło się także jako przestrzeń spotkań roboczych w większej grupie - postacie awatarów w żaden sposób nie ułatwiały nam komunikacji. Naiwne twarze kontrastowały z tonem głosu, brak mimiki dezorientował, co powodowało poczucie dysonansu i irytacji.

W odpowiedzi na liczne prośby użytkowników w lecie 2020 twórcy aplikacji wprowadzili zmiany w konstrukcji awatarów. Aktualnie dostają oni do dyspozycji rozbudowany edytor umożliwiający tworzenie awatarów dopasowanych do indywidualnego stylu i gustu. Zrezygnowano z nóg, ręce ograniczono do dłoni (rys. 2). Awatary mają teraz mimikę i gestykulację. Wydaje się, że twórcy wzorowali się na konkurencyjnej aplikacji Bigscreen, która od dawna stosuje podobne rozwiązania.

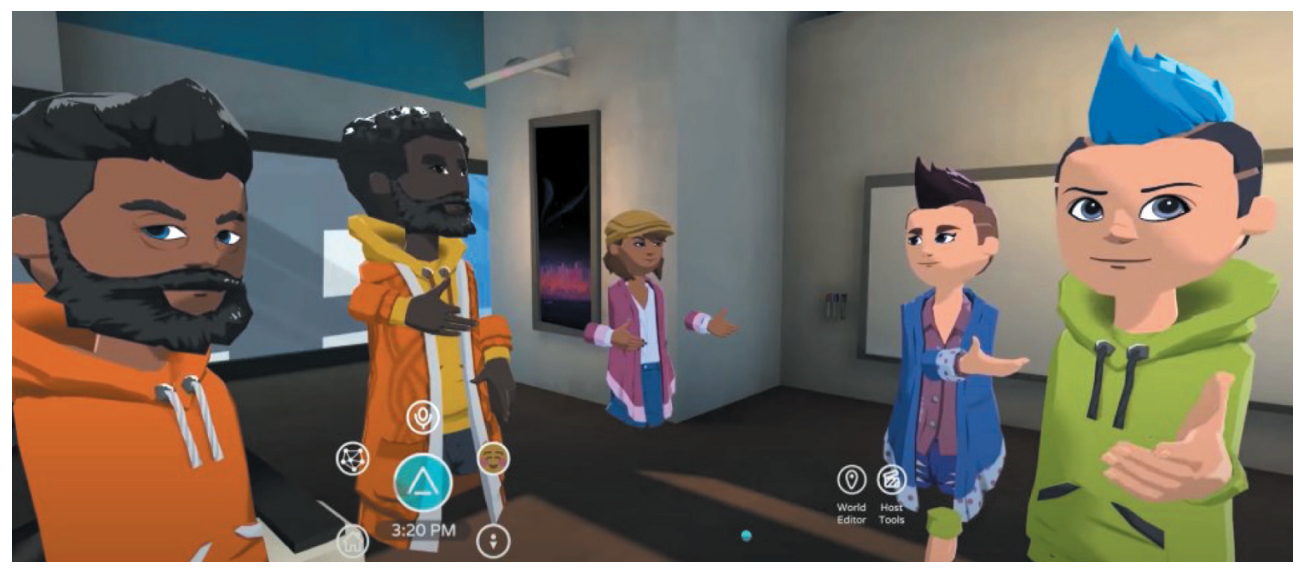

Rys. 2. Zapowiedź nowego wyglądu awatarów w aplikacji Altspace Źródło: https://altvr.com/new-avatars-coming-soon/ (lipiec 2020) 


\subsection{Engage - realistyczny everyman}

Profesjonalnym odpowiednikiem Altspace jest Engage: platforma edukacyjna i szkoleniowa, w odróżnieniu od Altspace nakierowana raczej na firmy i instytucje edukacyjne niż osoby prywatne. Skorzystać z jej narzędzi może jednak każdy, tworząc własne spotkanie, sesję czy szkolenie. Większość narzędzi jest darmowa, część dostępna za dodatkową opłatą. Składa się na nie obszerna biblioteka cyfrowych lokalizacji i obiektów służących do projektowania wirtualnych doświadczeń (Engage, b.d.).

Platforma stawia na realizm: biura wyglądają jak biura, sale konferencyjne jak sale konferencyjne, realistyczne mają być także awatary zachowujące ludzkie proporcje całego ciała. Mimo że awatary Engage wyglądają zupełnie inaczej niż klasyczne postacie Altspace, ich kreatorów łączy przekonanie, że nasze cyberciała mają być neutralne. Nie ma miejsca na ekstrawaganckie fryzury, krótkie spódnice czy duże biusty. Przestrzeń Engage zaludniają rzesze podobnych do siebie everymenów. Spersonalizowane awatary wyglądają całkiem nieźle na zdjęciach, w przestrzeni wirtualnej już znacznie gorzej: algorytm nie radzi sobie z ruchami nóg i rąk, które nienaturalnie wykręcają się jak u postaci z japońskich horrorów, niepokoi mimika twarzy - żywa, ale niewspółgrająca $\mathrm{z}$ tonem głosu. Śmiech kontrastujący z poważnym wyrazem twarzy daje nieprzyjemne wrażenie obcowania z brzuchomówcą (rys. 3).

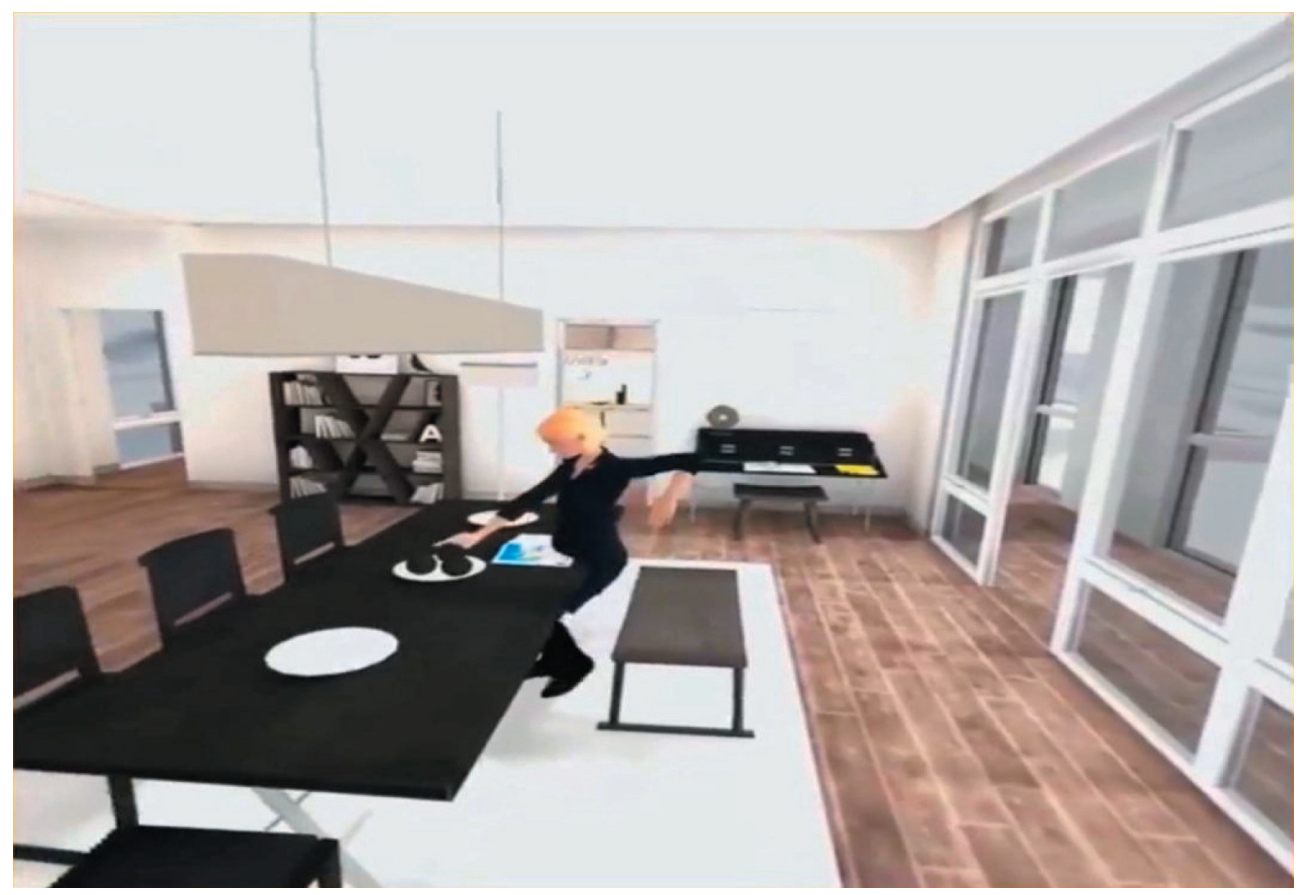

Rys. 3. Autorka w aplikacji Engage. Uwagę budzą nienaturalne ruchy ciała Źródło: zrzut z ekranu, widok aplikacji Engage (lipiec 2020) 
Gdy chcemy stworzyć filmowy obraz bezlitosnego przeciwnika, podkreślić jego obcość i brak emocji, możemy użyć zimnych, matowych oczu, posągowej nieruchomości, pozbawić bohatera subtelnych, automatycznych reakcji na bodźce ze świata. W efekcie uzyskujemy „terminatora” - istotę podszywającą się pod człowieka, która wygląda podobnie do niego, ale odmiennie czuje i reaguje. Ograniczenie możliwości oceniania na podstawie wyglądu zewnętrznego i odmienność odruchów awatara od ludzkich mogą łatwo wywołać podejrzliwość, aurę niepewności i poczucie zagrożenia. Nawet najbardziej realistyczne VR-owe awatary nie potrafią oddać w pełni niewerbalnych gestów, grymasów i niuansów twarzy, przez co są podatne na taki właśnie odbiór.

\subsection{Spatial - martwa kopia}

Na realizm stawia także jedna z najnowszych platform, Spatial, oferująca wirtualne przestrzenie biurowe. Awatary mają być nie tylko realistyczne, ale stanowić jak najdokładniejsze odwzorowanie wyglądu samych użytkowników. Podstawą do ich wygenerowania jest pojedyncze zdjęcie z kamerki zamontowanej w laptopie. Aparat frontalnie uchwytuje twarz, resztę dopisuje algorytm (rys. 4, 5).

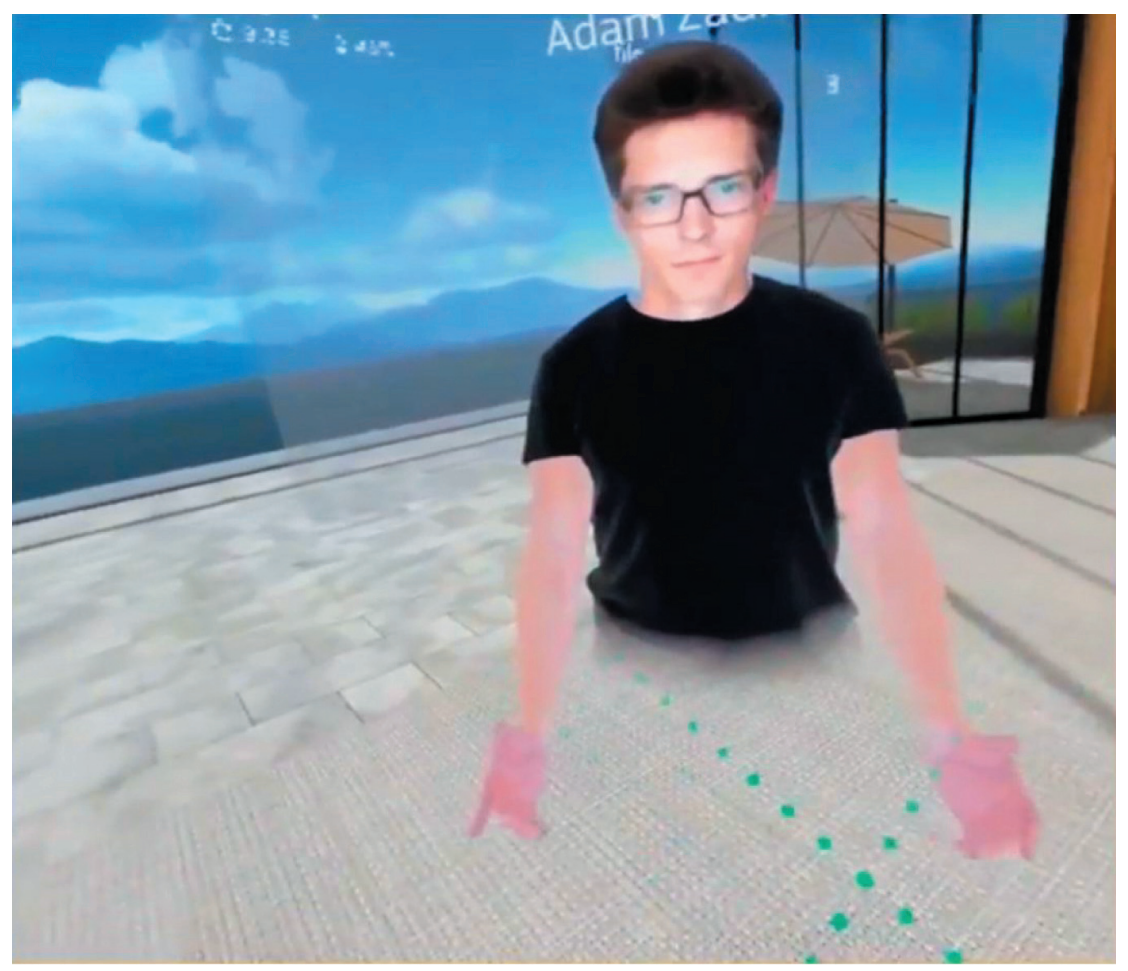

Rys. 4. Autor artykułu w Spatial

Źródło: zrzut z ekranu, widok aplikacji Spatial (lipiec 2020) 


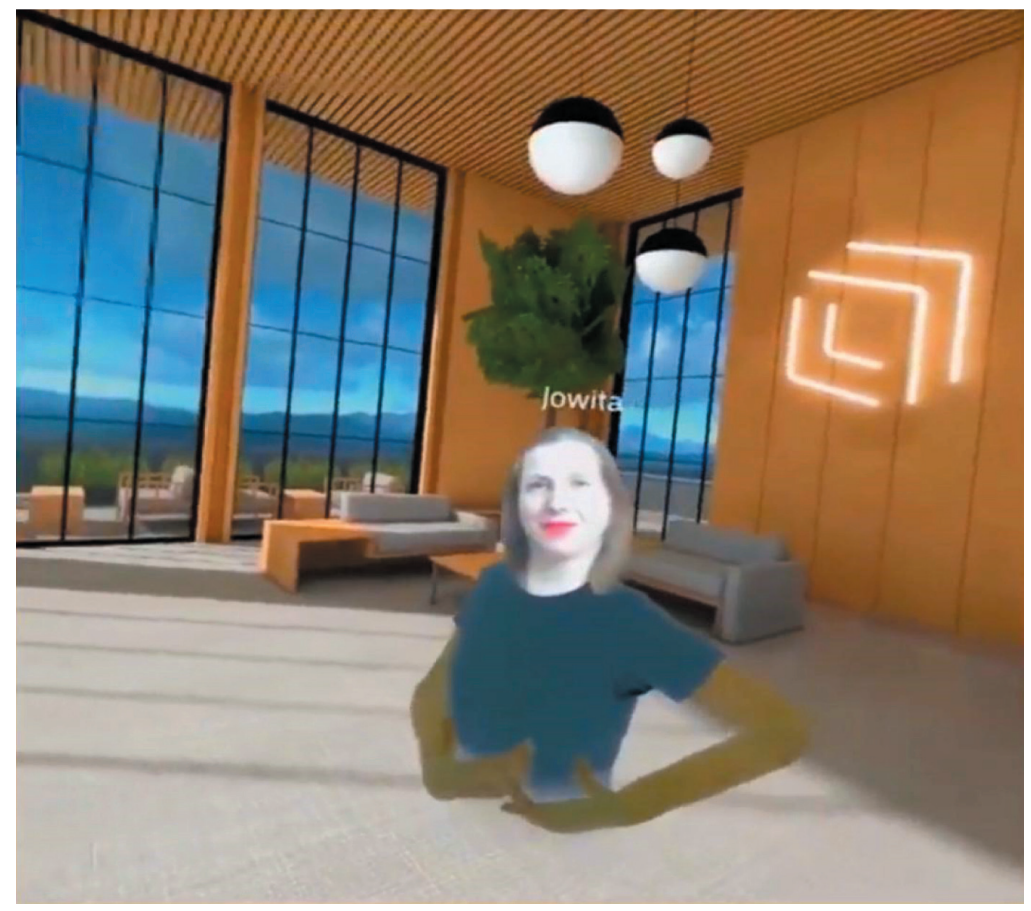

Rys. 5. Autorka artykułu w Spatial

Źródło: zrzut z ekranu, widok aplikacji Spatial (lipiec 2020)

Awatary w Spatial nie sprzyjają naturalnej interakcji. Twarze naszych rozmówców pozbawione są emocji, obserwują nas martwymi, nieruchomymi oczami, ręce nie przenoszą w pełni gestów, lewitują, „glitchują się" z torsem. Uproszczona mimika daje efekt maski z ruchomymi ustami i brwiami. Możliwość zobaczenia samego siebie w VR-owej wersji 3D jest początkowo atrakcją, jednak ciężko utożsamiać się ze „zglitchowaną”, uproszczoną imitacją własnej osoby. Technicznie VR nie jest obecnie przygotowany na awatary o wysokim stopniu realizmu, ale ważniejsze jest pytanie, czy my kiedykolwiek będziemy gotowi na konfrontację z kopią samych siebie.

Spotkanie sobowtóra, „prawie takiego jak oryginał, ale nie do końca”, budzi naturalny lęk od zawsze znany w kulturze i prezentowany w formie mitycznego doppelgängera w szeregu jej tekstów: od Wieczoru Trzech Króli Szekspira aż po cyberpunkowe obrazy androidów i klonów. To właśnie sobowtóry decydują o niesamowitości Opowieści Hoffmanna Offenbacha czy Akademii i Tryumfu Pana Kleksa Jana Brzechwy.

\subsection{VRChat - pełna performatywność}

„VRChat oferuje nieskończoną ilość społecznościowych doświadczeń VR, oddając swojej społeczności pełną moc tworzenia. Niezależnie od tego, czy szukasz nowych 
wrażeń VR, czy masz własny pomysł, VRChat to miejsce, w którym warto być” - czytamy na stronie twórców aplikacji (VRChat, b.d.).

Strategia konstrukcji awatarów przyjęta w aplikacji kompletnie odbiega od przedstawionych wyżej, stawiając na pełną performatywność. Tutaj każdy jest kimś (lub czymś) innym - do wyboru mamy setki awatarów z możliwością wgrywania i tworzenia własnych. Akceptowane są wszelkie stylistyki i detale. Platforma stawia przede wszystkim na wspólną rozrywkę i odgrywanie przez użytkowników rozmaitych ról, czemu sprzyja karnawałowe szaleństwo kreacji.

Jakość i realizm samych modeli awatarów są bardzo różne - to od wyborów użytkownika zależy, jaką formę przybierze. Funkcjonalność awatara schodzi na drugi plan, wiele postaci ma liczne „glitche”, niedopracowania, ograniczoną motorykę lub wręcz brak mimiki (rys. 6). Nieskrępowana swoboda wyboru sprawia jednak, że wybór/tworzenie awatara jest atrakcją samą w sobie. Sprzyja ona radykalnym, różnorodnym i śmiałym wyborom, a świat aplikacji jest kolorowy i zwariowany. W VRChacie rzadko odtwarzamy samych siebie. Naszych znajomych identyfikujemy bardziej po nicku i głosie niż ich wyglądzie/gestykulacji. Tutaj wyrazimy się najlepiej poprzez wybór ulubionego popkulturowego bohatera, subkultury lub stylistyki. Komunikację utrudnia jednak niedoskonała (lub żadna) mimika, w którą producenci aplikacji nie inwestują, w zamian za to stawiając na różnorodność. VRChat nie ma jednak służyć komunikacji tylko zabawie, chociaż w czasie pandemii jego przestrzeń bywa wykorzystywana także do tego.

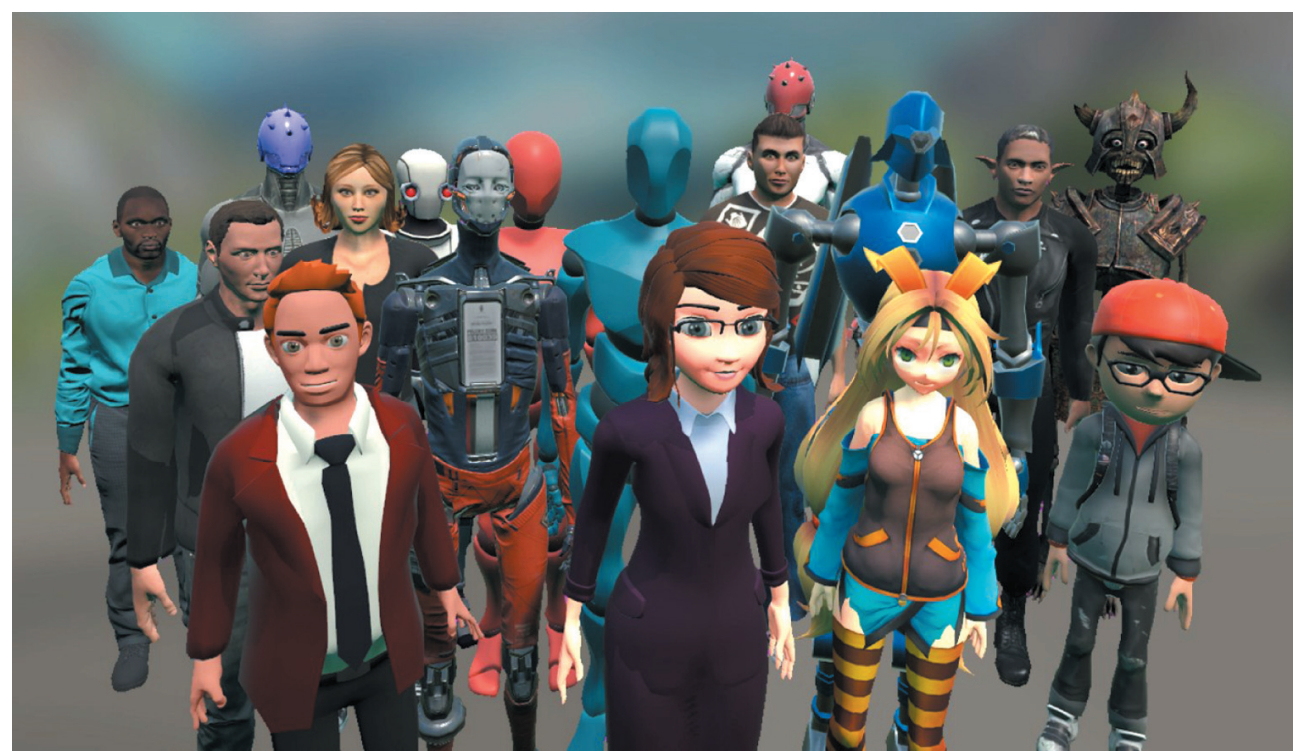

Rys. 6. Wygląd awatarów aplikacji VrChat Źródło: https://virtualrealitypop.com/vrchat-releases-early-access-build-12d1ee1986e8 (lipiec 2020) 


\subsection{Bigscreen - nasze komiksowe, ,ja"}

Przeznaczeniem aplikacji Bigscreen - czytamy na stronie producenta - nie ma być „budowanie «metaversum» czy sieci społecznościowej”. Zamiast tego - deklaruje „staramy się tworzyć przydatne narzędzia, które umożliwiają użytkownikom korzystanie z istniejących treści, aplikacji i gier w rzeczywistości wirtualnej oraz nawiązywanie kontaktów i spotykanie się we wspólnej przestrzeni VR z przyjaciółmi i współpracownikami. Bigscreen stara się odpowiedzieć na pytanie: w jaki sposób headsety VR i AR zmienią sposób, w jaki korzystamy z naszych komputerów?" (Bigscreen, b.d.). W rzeczywistości Bigscreen najlepiej spośród przytoczonych aplikacji spełnia się w komunikacyjnej roli. Projektanci zrezygnowali z realizmu postaci, stawiając na stylistykę przypominającą nieco japońską anime, ale mimo tego awatary oddają pewne indywidualne cechy wcielonej osoby. Edytor daje kontrolę nad rozmiarem, kształtem i kolorem włosów, brwi i oczu. Pozwala dopasować stopień smukłości ciała i zindywidualizować ubranie. Bazowy pozostaje kształt głowy, uszu i nosa.

W konstrukcji zastosowano znaną sztuczkę z animowanych filmów dla dzieci: Chcesz, żeby twoja postać była sympatyczna, nie będąc nawet człowiekiem? Postaw na wyrazistą, ekspresyjną mimikę i gestykulację, powiększ oczy, zastosuj regularne proporcje twarzy i symetryczne krzywizny ciała (rys. 7).

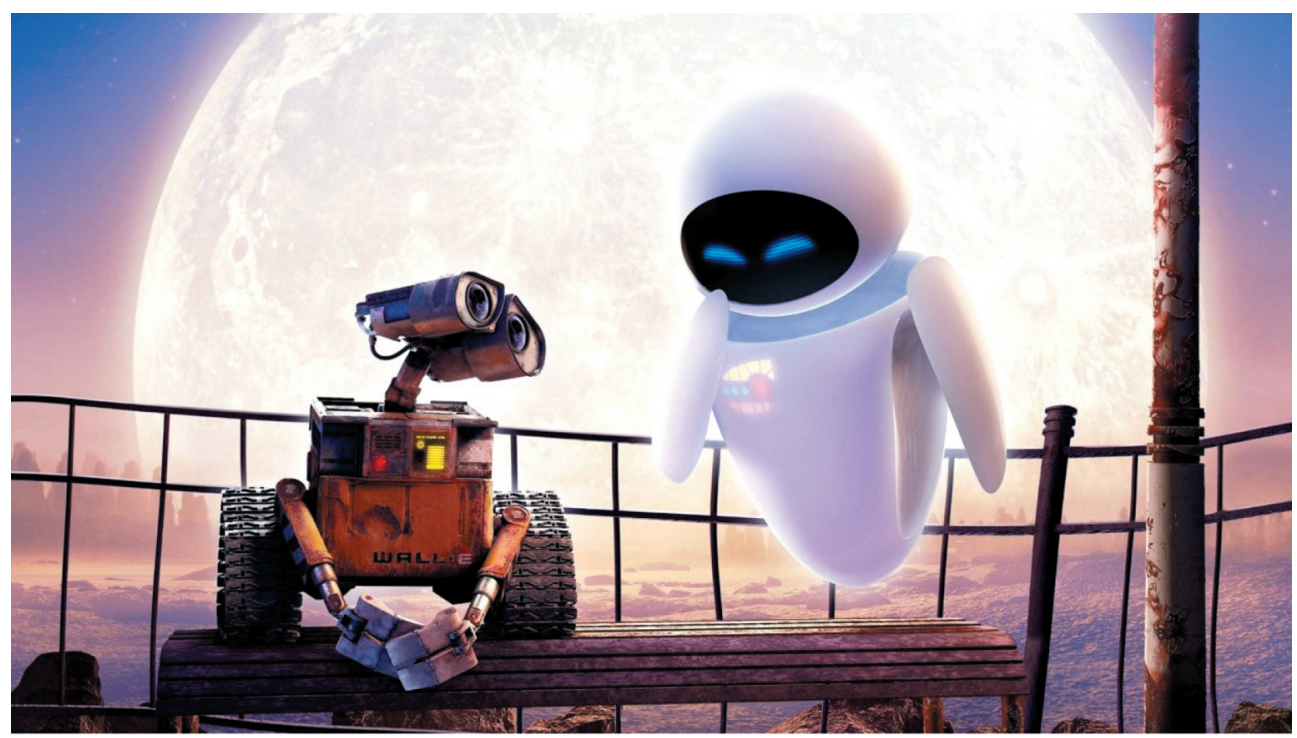

Rys. 7. Przykład tej samej strategii, ale zastosowanej w kontekście filmowym.

Grafika promocyjna i kadr z filmu animowanego WALL-E

(2008, reż. Andrew Stanton; produkcja Pixar Animation Studios i Walt Disney Pictures)

Źródło: https://www.fajnedziecko.pl/wall-e-2008/ (lipiec 2020) 
W aplikacji Bigscreen bardzo duże oczy z uwagą śledzą rozmówcę, usta są niewielkie i na tyle neutralne, że dysonans między wyrazem twarzy a tonem głosu niemal nigdy się nie pojawia. Postacie mają bardzo uproszczone sylwetki - korpusy bez rąk i nóg, ciała operują jedynie zawieszonymi w powietrzu dłońmi (rys. 8). Za to aplikacja bardzo dobrze przenosi sposób gestykulacji dłoni oraz ruchy szyi. Rozpoznawanie ich jest na tyle czułe, że na podstawie samego ruchu można rozpoznać swojego znajomego (rys. 9).

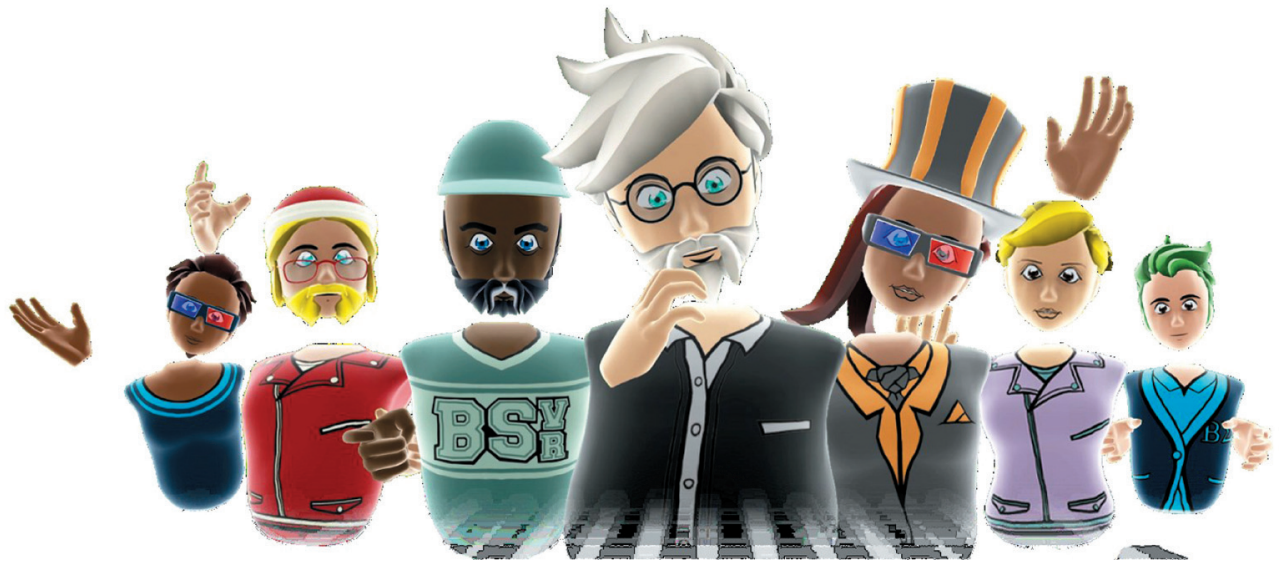

Rys. 8. Projekty awatarów aplikacji Bigscreen

Źródło: https://www.phoneweek.co.uk/bigscreen-overhaul-brings-big-improvements-newfeatures-to-all-supported-platforms-road-to-vr/ (lipiec 2020)

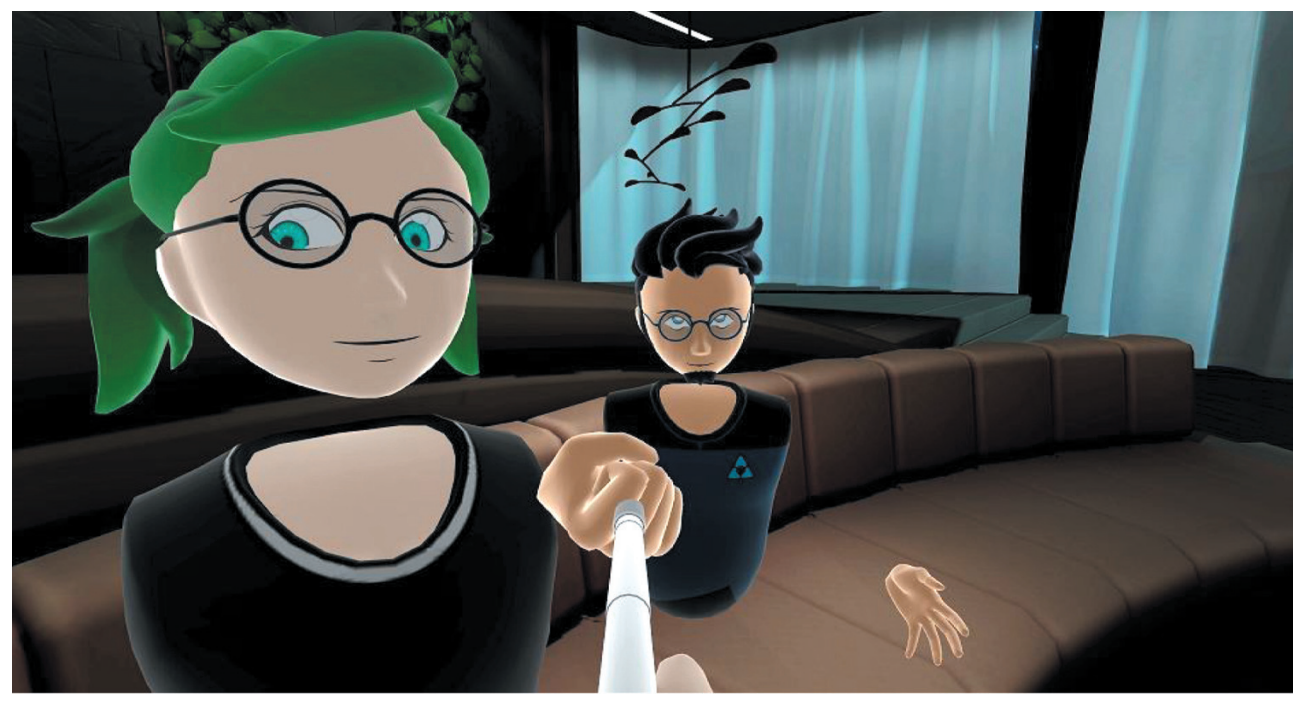

Rys. 9. Projekt awatarów w aplikacji Bigscreen: autorka artykułu robiąca „selfie” ze znajomym Źródło: zrzut z ekranu, widok aplikacji Spatial (lipiec 2020) 
Bigscreen jest aplikacją odbieraną przez użytkowników jako przyjazna i komfortowa. W czasie wiosennego lockdownu była popularnym miejscem spotkań, przyciągała nawet seniorów. Wykreowane w niej awatary nie są przeszkodą w komunikacji, pomimo skromnych środków zapewniają doświadczenie rozmowy twarzą w twarz we wspólnej przestrzeni.

\section{Podsumowanie}

Przeprowadzone badania wykazały szereg problemów, jakie niesie ze sobą komunikacja w VR. Chociaż mamy za sobą wieloletnie doświadczenia z komunikacją cyfrową, zaprojektowanie środowiska VR wspierającego komunikację okazuje się znacznie bardziej wymagającym zadaniem. Chociaż spotykamy się w postaci awatarów, przestrzeń tego spotkania odbieramy jako fizyczną. VR angażuje ciało, lepiej lub gorzej oddając nasze gesty i mimikę. Nasze awatary nie są już marionetkami, którymi sterujemy za pomocą trzymanych w rękach padów lub myszki - dosłowne „wchodzimy” w cyberskórę. Taki poziom immersji jest największą siłą komunikacji w VR, ale jednocześnie psychologicznym ryzykiem i antropologicznym eksperymentem. Sposób, w jaki doświadczamy bliskości i obcości drugiego człowieka oraz własnego ciała, jest czymś nowym. Niezwykłość tego doświadczenia staje się namacalna, gdy wędrujemy po wirtualnych światach: czasem zaskakuje nas poczucie lęku, niesamowitości i dysonansu, a czasem głębi porozumienia i autentyczności kontaktu. Wstępne badania wykazują, że u podłoża problemu z projektowaniem środowisk do komunikacji VR leżą jednak nie tylko kwestie techniczne, ale przede wszystkim rozstrzygnięcia o charakterze antropologicznym dotykające takich problemów jak tożsamoć, autentyczność i ich relacje z naszą cielesnością.

W 2008 roku Michał Ostrowicki pisał: „Urodziłem się w Second Life 11 października 2007 roku. Najpierw przyjąłem imię sieciowe, następnie przybrałem elektroniczne ciało. Potem obraz rozpadł się, powstała przestrzeń. Interaktywność zassała intencjonalność. Wszedłem w elektroniczny świat" (Ostrowicki 2008: s. 143). Sidey Myoo - jak tytułuje się odtąd krakowski uczony - funkcjonując jednocześnie w dwóch światach (,zwyczajnym” i Second Life) już wtedy badał zjawisko telematyczności, czyli zdolności zmysłowego odczuwania w środowisku elektronicznym (Ostrowicki 2009: s. 160). W sytuacji, w której przebywanie w cyfrowym świecie staje się dla człowieka naturalnym i codziennym, telematyczność staje się „szóstym zmysłem” - doświadczeniem o swoistym charakterze, które znacząco zmienia nasz odbiór świata. Rozwinięcie technologii VR z kolei znacząco poszerzyło obszary cyfrowego doświadczenie, co każe podjąć na nowo temat telematyczności oraz tożsamości człowieka zamieszkującego świat cyfrowy. 
Teoria uczestnictwa w cyfrowym świecie w postaci cyberciała często wiązana jest z teorią teatru. Takie podejście reprezentują Janet Murray (1997), Gonzalo Frasca (2001), Michael Mateas (2004), Rafał Kochanowicz (2014) i Michał Kłosiński (2018). Tradycyjne techniki teatralne opierają się na immersji, jest ona niezbędnym elementem wczucia aktora w rolę. Podobnie dzieje się, gdy wcielamy się w cyberpostać. Odgrywając rolę, wyrażamy jednocześnie samych siebie. Wspomniani badacze rozważają tę kwestię w kontekście gier wideo, ale problem relacji gry, fikcji i naszej tożsamości ma charakter uniwersalny. Eksplikuje to Kłosiński (2018), analizując sytuację gracza z perspektywy hermeneutyki Paula Ricoeura i Martina Heideggera. Nasza tożsamość mówią hermeneuci - z zasady ma charakter narracyjny i performatywny. Jej ustanawianie to ciagły proces autointerpretacji, opowiadania siebie samemu sobie (Heidegger) zapośredniczony w kulturowych tekstach, fikcjach i rolach (Ricoeur). Pytanie, w jaki sposób na proces ten wpływa charakter medium, którego używamy do rozwijania autonarracji.

Kłosiński przywołuje słowa teoretyka teatru, Esy Kirkkopelto, o cielesności wyobraźni: „Nie jesteśmy w stanie wskazać, w którym miejscu wyobraźnia zmienia się w doświadczenie cielesne i vice versa. Przeciwnie, powinniśmy myśleć o wszelkiej wyobraźni jako cielesnej, nawet w naszych snach na jawie, gdy ciało śniącego jedynie odgrywa martwe. Ograniczenia ludzkiego doświadczenia, jeśli rzeczywiście są ograniczeniami, nie mogą być całkowicie naszymi własnymi: są one czymś, co dzielimy z tym, czym nie jesteśmy. Jeśli wyobraźnia i gra, jako dwa podstawowe dynamiczne aspekty doświadczenia, są w stanie wyśledzić i, do pewnego stopnia, usunąć te ograniczenia, to obie te czynności pracują tak, aby również połączyć nas z tym, co nieznane, nie czyniąc tego automatycznie «znanym» i naszym «własnym»" (Kirkkopelto 2015, za: Kłosiński 2018: s. 125).

Cyfrowe medium jest właśnie „nieznanym”, które zarazem ułatwia performatywność i stawia jej opór. Uwalnia od ograniczeń ciała fizycznego, zrównując je z ciałem wykreowanego przez nas awatara, ale jednocześnie nakłada ograniczenia innego typu: software'owe, czyli narzucone przez projektanta schematy i modele, oraz te wynikajace z hardware'u. W Second Life i klasycznych grach wideo tożsamość podmiotu eksplorującego świat cyfrowy rozdwaja się na ,ja” przed ekranem i ,ja” sterowane za pomocą myszki czy pada. Technologia VR zmierza do integracji: cyberciało ma być „moim” ciałem w pełnym tego słowa znaczeniu. Służą temu śledzenie ruchów ciała fizycznego, które integruje je z wirtualnym, eye trackery, kombinezony i rękawice haptyczne oraz szereg zaawansowanych interfejsów takich jak specjalne maty czy bieżnie minimalizujące ryzyko wytrącenia z immersji. Rozwój technologii VR ukierunkowany jest na zapewnienie użytkownikowi wcielenia totalnego, ale czy rzeczywiście świat zaludniony awatarami Engage, Spatial czy Altspace jest tym, w który chcielibyśmy się wcielić? 
Teoretycznie second life w VR to tylko krok dalej od Second Life badanego przez Sideya Myoo. W praktyce zanurzeni w rzeczywistości wirtualnej, wszystko odbieramy znacznie mocniej, niż siedząc przed ekranem komputera. VR gorzej toleruje umowność wykreowanego świata, nie pozwala na dystans, stawiając opór wyobraźni. Sprawia to, że molestowanie, lęk, poczucie obcości czy niesamowitości są dla osoby ich doświadczającej bardzo dotkliwe i trudne do zneutralizowania. W tej sytuacji projektant aplikacji społecznościowych chcąc nie chcąc staje się reżyserem nawiązanych w niej kontaktów: może wrzucić nas w świat przyjazny (Bigscreen), ryzykowny (Altspace, VRChat) bądź do „doliny niesamowitości” (Spatial).

Chociaż z branżowego punktu widzenia to hardware jest największym ograniczeniem technologii VR, z perspektywy użytkownika analizowanych aplikacji problem ten jest drugo-, a nawet trzecioplanowy. Przeszkodą nie jest także poziom grafiki, a „glitche” są możliwe do naprawienia. Problem tkwi w antropologicznych założeniach, które towarzyszą projektantom. Za każdą z przyjętych strategii konstrukcji awatarów stoi określony model relacji podmiotu i ciała. W strategii „neutralny everyman” przebrzmiewa dualizm platońskiego typu: ciało jest „pojemnikiem” na umysł/duszę. Niewiele wnosi, za to przeszkadza, należy więc sprawić, aby ciało/awatar było niewidoczne i dać wybrzmieć temu, co „w środku”. Na drugim krańcu znajduje się strategia „tworzenia kopii” zakładająca dla odmiany całkowity monizm - możemy „pozostać sobą” jedynie wtedy, gdy zachowane zostaną detale naszego ciała. Gdzieś pomiędzy leżą takie rozwiązania jak w Bigscreen: być może nie muszę zachować swojego ciała, aby nadal być sobą, ale pewne elementy mojej indywidualności muszą afirmować się w sposób cielesny? Jaki model ciało-podmiot za tym stoi?

Virtual Reality i doświadczenia, które mamy w tej przestrzeni, dają nam zupełnie nowy wgląd w to, czym jest podmiot, autentyczność, tożsamość, a także komunikacja. Jak ważne jest dla innych, abyśmy pozostali w ,swoich” ciałach, a nie stworzyli siebie od nowa? Jak daleko możemy się posunąć, żeby nie zatracić swojej indywidualności? Czy cyberciało jest „moje” w taki sam sposób jak ciało fizyczne? A może należy nie do mnie tylko do projektanta aplikacji? Są to pytania, które dopiero zaczynamy sobie zadawać.

\section{Literatura}

AltspaceVR, b.d., https://altvr.com/ [dostęp: 6.06.2020].

Bigscreen, b.d., About Us, https://www.bigscreenvr.com/about [dostęp: 6.06.2020].

Controversy Regarding „VR Sexual Harassment”, b.d., Reddit, https://www.reddit.com/r/

AltspaceVR/comments/4khlfw/controversy_regarding_vr_sexual_harassment/ [dostęp: 10.11.2020].

Engage, b.d., https://engagevr.io/\#about [dostęp: 6.06.2020]. 
Frasca G., 2001, Rethinking Agency and Immersion: Video Games as a Means of Consciousness-Rising, Digital Creativity, vol. 12(3), s. 167-174. https://doi.org/10.1076/ digc.12.3.167.3225.

Kirkkopelto E., 2015, The Ethics of Gastropods. An Analysis of a Trans-Human Practice, Eurozine, https://www.eurozine.com/the-ethics-of-gastropods/ [dostęp: 18.04.2018].

Kłosiński M., 2018, Hermeneutyka gier wideo. Interpretacja, immersja, utopia, Instytut Badań Literackich PAN, Warszawa.

Kochanowicz R., 2014, Fabularyzowane gry komputerowe w przestrzeni humanistycznej: analizy, interpretacje $i$ wnioski z pogranicza poetyki, aksjologii, dydaktyki literatury, Wydawnictwo Uniwersytetu Poznańskiego, Poznań.

Mateas M., 2004, A Preliminary Poetics for Interactive Drama and Games, [w:] Wardrip-Fruin N., Harrigan P. (eds.), First Person: New Media as Story, Performance and Game, MIT Press, Cambridge, s. 1-26.

Murray J., 1997, Hamlet on the Holodeck: The Future of Narrative in Cyberspace, MIT Press, Cambridge.

Ostrowicki M. (Sidey Myoo), 2008, Tożsamość człowieka w środowisku elektronicznym, Kwartalnik Filmowy, R. 30, nr 62/63, s. 143-152.

Ostrowicki M. (Sidey Myoo), 2009, Doświadczenie telematyczne w rzeczywistości elektronicznego realis. Odczuwanie, Kultura Współczesna, nr 3(61), s. 160-172.

Pullen J.P., 2016, This Startup Is Solving Virtual Reality's Biggest Problem, Time, 19 January, https://time.com/4185359/altspace-virtual-reality/ [dostęp: 10.11.2020].

Sexual Harassment on AltspaceVR a problem?, b.d., Reddit, https://www.reddit.com/r/ AltspaceVR/comments/5nd3n4/sexual_harassment_on_altspacevr_a_problem/ [dostęp: 10.11.2020].

VRChat, b.d., https://hello.vrchat.com/ [dostęp: 6.06.2020]. 